Keio J. Med. 28: 139-149, 1979

\title{
THE PRESENT AND PROVISIONAL STATE OF AUXILIARY PERSONNEL IN EYE CARE IN JAPAN
}

\author{
YASUO UEMURA and KENICHI AKIYAMA \\ Department of Ophthalmology, School of Medicine, \\ Keio University, Tokyo, Japan
}

(Received for publication December 1, 1979)

\begin{abstract}
The task of auxiliary personnel in eye care differs considerably from country to country. To illustrate an over all picture of eye care in Japan may help understanding the inter-relationship of different auxiliary personnels and useful for international comparison as a pertient reference. Auxiliary personnel assisting in ophthalmic practice includes orthoptist, ophthalmic medical assistant, ophthalmic nurse and optician or optometrist.

Orthoptist and ophthalmic medical assistant have recently been introduced to the ophthalmic practice in Japan, and for this reason described in some detail.

Optician and optometrist in relation to ophthalmologist have become an important and popular topic among the people concerned. Some of the problems involved were briefly discussed.

Health care of the eye and screening of eye diseases in different communities were described. The job of personnel engaged in rehabilitation of the visually handicapped, and auxiliary personnel working in emergency situation were also stated.
\end{abstract}

When we think of the auxiliary personnel in eye care comprehensively from world-wide viewpoint, not only present situations in different countries with different eye diseases and eye cares, but ideal plans for the future for each country should be taken into account. The purpose of this paper is to illustrate the present and provisional state of auxiliary personnel in eye care in Japan.

Just as medical care necessitated the participation of X-ray technician, laboratory technician, pharmacist, dietician, physical therapist, speech therapist and other paramedical personnels, an advanced eye care requires an extensive help from auxiliary personnels. Figure 1 illustrates an over all system of eye care in Japan. The main feature in the primary eye care to the tertiary eye care is the task of ophthalmologist. It is important to have a comprehensive 


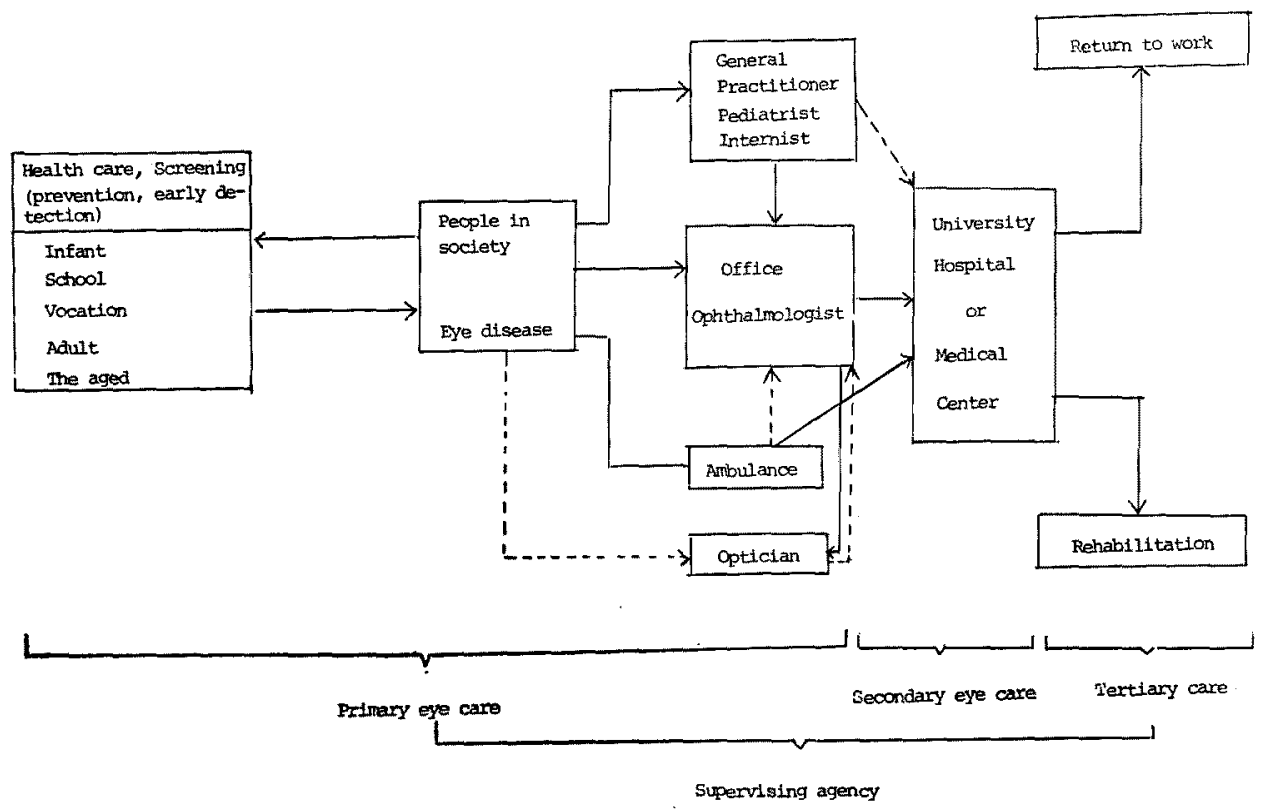

Fig. 1 Over all system of eye care.

continuity in administration of eye care from prevention to rehabilitation. It is also important to have an agent in the system for constant monitoring and supervision.

With this over all system of eye care in mind, we would like to discuss the specific task and training of auxiliary personnel in eye care. We have divided the task of auxiliary personnel into four categories.

1. Assistance in ophthalmic practice

2. Health care of the eye and screening of eye diseases

3. Rehabilitation of the visually handicapped

4. First aid for eye emergencies

\section{Assistance of Ophthalmic Practice}

As modern ophthalmic practice evolved from "red eye clinic" to "white eye clinic", diagnostic tests and procedures became numerous and complicated with various kinds of instruments and machines. This trend inevitably produced a need for auxiliary personnel.

About 25 years ago in Japan, ophthalmologists convened to discuss the concept of having various auxiliary personnel involved in ophthalmic practice and 
the following categories were adopted:

a) Examination and training of amblyopia and strabismus $\ldots \ldots \ldots \ldots \ldots \ldots \ldots \ldots \ldots$ Orthoptist

b) Examinations of visual acuity, refraction, accommodation and contact lens ............. Optometrist

c) Qualitative visual field examination $\ldots \ldots \ldots \ldots \ldots \ldots$ Perimetrist

d) Intraocular pressure and tonography $\ldots \ldots \ldots \ldots \ldots$ Tonometrist

e) Medical photography of fundus and the anterior segment $\ldots \ldots \ldots \ldots \ldots \ldots \ldots \ldots$ Photographist

f) Medical electronics engineer (ERG, EOG, VEP, etc.) ............. Medical Electronician

g) Craftsman for prosthesis $\ldots \ldots \ldots \ldots \ldots \ldots \ldots \ldots \ldots$ Ocularist

Among these, only orthoptist has been approved by law as an occupational category.

1) Orthoptist

The orthoptist was recognized and approved by the Japanese Ophthalmological Society in 1969. In 1971 the orthoptist was approved by law and two training institutions were opened in Tokyo and Osaka in affiliation with the Japanese national hospitals. Each year a total of 60 students graduate from these schools. A third private training school for the orthoptist opened in Niigata in 1977. Qualifications to enter these institutions are high school graduation for the three year course and college graduation for the one year course. Curriculum and requirements of these schools are shown in Tables 1 and 2. A national examination is performed annually and licenses are given to those who pass the examination. The examination covers clinical psychology, anatomy-physiology-pathology of the visual organ, visual physiology, physiological optics, ophthalmic disease entities, ophthalmic pharmacology, and orthoptics.

According to Japanese law, an orthoptist is a person who, under the supervision of an ophthalmologist, performs corrective training and necessary examination to restore binocular vision in those whose binocular function is disabled.

After obtaining their license, most orthoptists work in medical centers or university hospitals to extend their experience and training. The Japanese Orthoptic Association sponsors two or three seminars and two conferences per year to refresh the learning of the orthoptists.

Table 3 shows the places where orthoptists have been employed. Many of them are employed by private university hospitals but only a few by national 
Table 1

Curriculum of school for orthopist (three year course)

\begin{tabular}{|c|c|c|c|c|}
\hline & \multirow{2}{*}{ Subject } & \multicolumn{3}{|c|}{ Required time in hours } \\
\hline & & Lecture & $\begin{array}{c}\text { Laboratory } \\
\text { work }\end{array}$ & Total \\
\hline $\begin{array}{l}\text { Basic } \\
\text { subject }\end{array}$ & $\begin{array}{l}\text { Pedagogy } \\
\text { Ethics } \\
\text { Psychology } \\
\text { Gymnastics } \\
\text { Biology } \\
\text { Social welfare } \\
\text { Psychological hygiene } \\
\text { Nursing } \\
\text { Mathematics - Statistics } \\
\text { Physics } \\
\text { Foreign language } \\
\text { Law } \\
\text { Medical ethics } \\
\text { Anatomy · Physiology } \\
\text { Public health } \\
\text { Clinical psychology } \\
\text { Pediatric disease entities }\end{array}$ & $\begin{array}{r}60 \\
30 \\
60 \\
15 \\
15 \\
15 \\
30 \\
30 \\
15 \\
15 \\
180 \\
\\
15 \\
30 \\
30 \\
15 \\
15\end{array}$ & $\begin{array}{l}45 \\
45 \\
45 \\
90\end{array}$ & $\begin{array}{r}60 \\
30 \\
60 \\
60 \\
60 \\
60 \\
30 \\
120 \\
15 \\
15 \\
180 \\
15 \\
75 \\
30 \\
15 \\
15\end{array}$ \\
\hline $\begin{array}{l}\text { Specific } \\
\text { subject }\end{array}$ & $\begin{array}{l}\text { Anatomy · Physiology } \\
\text { Pathology of visual } \\
\text { organ } \\
\text { Visual physiology } \\
\text { Physiological optics } \\
\text { Pphthalmic disease } \\
\text { entities } \\
\text { Ophthalmic pharmacology } \\
\text { Neuro-ophthalmology } \\
\text { Orthoptics (general) } \\
\text { Orthoptics (specific) }\end{array}$ & $\begin{array}{r}60 \\
45 \\
30 \\
30 \\
30 \\
30 \\
150 \\
240\end{array}$ & 45 & 150 \\
\hline & Total & 1185 & 945 & 2130 \\
\hline
\end{tabular}

hospitals. This is probably because national hospitals have a low allowance of new employment. The Japanese Ophthalmological Society has appealed to the Ministry of Education, Deans of the national universities and hospitals in order that they might hire more orthoptists. Thanks to those efforts, several national universities have set up orthoptic departments and gradually more and more orthoptists have been employed by the government. Only $11 \%$ work in the offices 
Table 2

Curriculum of school for orthoptist (one year course)

\begin{tabular}{|c|c|c|c|c|}
\hline & \multirow{2}{*}{ Subject } & \multicolumn{3}{|c|}{ Required time in hours } \\
\hline & & Lecture & $\begin{array}{c}\text { Laboratiry } \\
\text { work }\end{array}$ & Total \\
\hline $\begin{array}{l}\text { Basic } \\
\text { subject }\end{array}$ & $\begin{array}{l}\text { Mathematics - Statistics } \\
\text { Physics } \\
\text { Law } \\
\text { Medical ethics } \\
\text { Anatomy - Physiology } \\
\text { Public health } \\
\text { Clinical psychology } \\
\text { Pediatric disease entities }\end{array}$ & $\begin{array}{l}15 \\
15 \\
15 \\
30 \\
15 \\
15 \\
15\end{array}$ & 45 & $\begin{array}{l}75 \\
15 \\
15 \\
15\end{array}$ \\
\hline $\begin{array}{l}\text { Specific } \\
\text { subjct }\end{array}$ & $\begin{array}{l}\text { Anatomy - Physiology } \\
\text { Pathologyof visual } \\
\text { organ } \\
\text { visual physiology } \\
\text { Physiological optics } \\
\text { Ophthalmic disease } \\
\text { entities } \\
\text { Ophthalmic pharmacology } \\
\text { Neuro-ophthalmology } \\
\text { Orthoptics (general) } \\
\text { Orthoptics (specific) }\end{array}$ & $\begin{array}{r}30 \\
30 \\
30 \\
15 \\
15 \\
15 \\
150 \\
240\end{array}$ & $\begin{array}{l}45 \\
45\end{array}$ & $\begin{array}{r}105 \\
75\end{array}$ \\
\hline \multicolumn{2}{|r|}{ Total } & 645 & 660 & 1305 \\
\hline
\end{tabular}

Table 3

Employment of orthoptist (June, 1976)

\begin{tabular}{l|c|c}
\hline \multicolumn{1}{c|}{ Place of employment } & No. of orthoptist & $\%$ of total orthoptist \\
\hline National hospital & 20 & 4 \\
National university hopital & 33 & 7 \\
Public hospital & 78 & 16 \\
Private university hospital & 78 & 16 \\
Private hospital and clinic & 115 & 24 \\
Red Cross hospital & 22 & 5 \\
Medical center & 74 & 15 \\
Others & 4 & 1 \\
Not employed & 58 & 12 \\
\hline \multicolumn{1}{c|}{ Total } & 482 & 100 \\
\hline
\end{tabular}


of practicing ophthalmologists.

Geographical distribution of orthoptists is shown in Table 4. Two thirds of the orthoptists are concentrated in the Tokyo area. In seven prefectures there is no orthoptists. Employment of orthoptists by national university hospitals and the correction of uneven geographic distribution are two immediate goals which we are trying to attain at present.

The first graduates of the three year course will emerge this year making the total yearly supply of $\mathbf{9 0}$ orthoptists. And yet, orthoptists are still in demand since about $10 \%$ of orthoptists ceases to work each year from various reasons.

Table 4

Geographical distribution of orthoptists (June, 1976)

\begin{tabular}{|c|c|c|c|c|c|c|c|c|c|}
\hline Prefecture & $\begin{array}{l}\text { Tokyo } \\
\text { School }\end{array}$ & $\begin{array}{l}\text { Osaka } \\
\text { School }\end{array}$ & $\begin{array}{l}\text { Spe- } \\
\text { cial }\end{array}$ & Total & Prefecture & $\begin{array}{l}\text { Tokyo } \\
\text { School }\end{array}$ & $\begin{array}{l}\text { Osaka } \\
\text { School }\end{array}$ & $\begin{array}{c}\text { Spe-- } \\
\text { cial }\end{array}$ & Total \\
\hline Eokkaido & 3 & & 3 & 6 & Fukui & & & 1 & 1 \\
\hline Aomori & 1 & & 2 & 3 & Ishikawa & & & 2 & 2 \\
\hline Iwate & & & & - & Toyama & & & & - \\
\hline Akita & 2 & & 1 & $\mathbf{3}$ & Tottori & & & 3 & 3 \\
\hline Yamagata & & & 1 & 1 & Shimane & & & & - \\
\hline Miyagi & 2 & & 2 & 4 & Okayama & 10 & & 11 & 21 \\
\hline Fukushima & & & & - & Hiroshima & 2 & & 6 & 8 \\
\hline Tokyo & 68 & 1 & 52 & 121 & Yamaguchi & & & 5 & 5 \\
\hline Kanagawa & 20 & & 15 & 35 & Kagawa & & 1 & 5 & 6 \\
\hline Chiba & 4 & & 12 & 16 & Tokushima & 2 & & 1 & 3 \\
\hline Ibaragi & 1 & & 2 & 3 & Kochi & 1 & 1 & 5 & 7 \\
\hline Tochigi & 2 & & 2 & 4 & Ehime & 1 & 1 & 4 & 6 \\
\hline Saitama & 6 & & 4 & 10 & Fukuoka & 3 & 1 & 6 & 10 \\
\hline Gunma & & & 1 & 1 & Saga & & & & - \\
\hline Yamanashi & 3 & & & 3 & Nagasaki & 1 & & 1 & 2 \\
\hline Nagano & 2 & & & 2 & Kumamoto & 1 & & 4 & 5 \\
\hline Niigata & 2 & & 3 & 5 & Oita & & & & - \\
\hline Shizuoka & & & 3 & 3 & Miyazaki & & & 4 & 4 \\
\hline Aichi & 6 & 1 & 28 & 35 & Kagoshima & & & & - \\
\hline Gifu & & & 2 & 2 & Okinawa & 1 & & & 1 \\
\hline Mie & & & 3 & 3 & Outside & & & & \\
\hline Osaka & 9 & 12 & 65 & 86 & Japan & 1 & & 2 & 3 \\
\hline Kyoto & & 1 & 4 & 5 & Total & 157 & 25 & 300 & 482 \\
\hline Shiga & & 1 & 5 & 6 & & & & & \\
\hline Nara & & & 8 & 8 & & & & & \\
\hline Wakayama & & & 5 & 5 & & & & & \\
\hline Hyogo & 3 & 5 & 17 & 25 & & & & & \\
\hline
\end{tabular}


2) Ophthalmic Medical Assistant

For general office ophthalmologists, orthoptists are not available and office nurses are too busy to do vision check, visual field, tonography and other numerous examinations. In order to meet this need of the general ophthalmologists, the Japanese Association of Ophthalmologists has been trying to establish a system of ophthalmic medical assistant on a legal basis. However, the present law concerning medical practice does not coincide with the suggested tasks of ophthalmic medical assistant (Table 5).

\section{Table 5}

Suggested tasks of ophthalmic medical assistant (1976, Japanese association of ophthalmologists)
1. Vision
2. Visual field
3. Lensometer
4. Contact lens assistance
5. Color vision
6. Keratometer
7. Accommodation and convergence
8. Binocular function
9. Photography of anterior segment and fundus
10. Refraction

In spite of this difficult legal situation, the Japanese Association of Ophthalmologists set up a special committee on this matter in 1976. Following the report of this committee, a one year curriculum was prepared and the plan (Table 6) is presently being pursued with self-trained office assistants. The curriculum consists of home study with texts and about 30 hours of schooling provided by the local ophthalmologists. The first examination was performed in May, 1979.

We are of the opinion that the task of the ophthalmic medical assistants is the subject to change according to the requirements of the time and the development of ophthalmic practice. The place of work of these assistants and their relationship to ophthalmologists are important considerations. In Japan, the ophthalmic medical assistants will perform their jobs in clinics or hospitals under the direct supervision of ophthalmologists.

3) Ophthalmic nurse

Registered nurse and practical nurse can become ophthalmic nurse after gaining practical experience in eye offices for an extended length of time. 
Table 6

Curriculum to train ophthalmic medical assistant

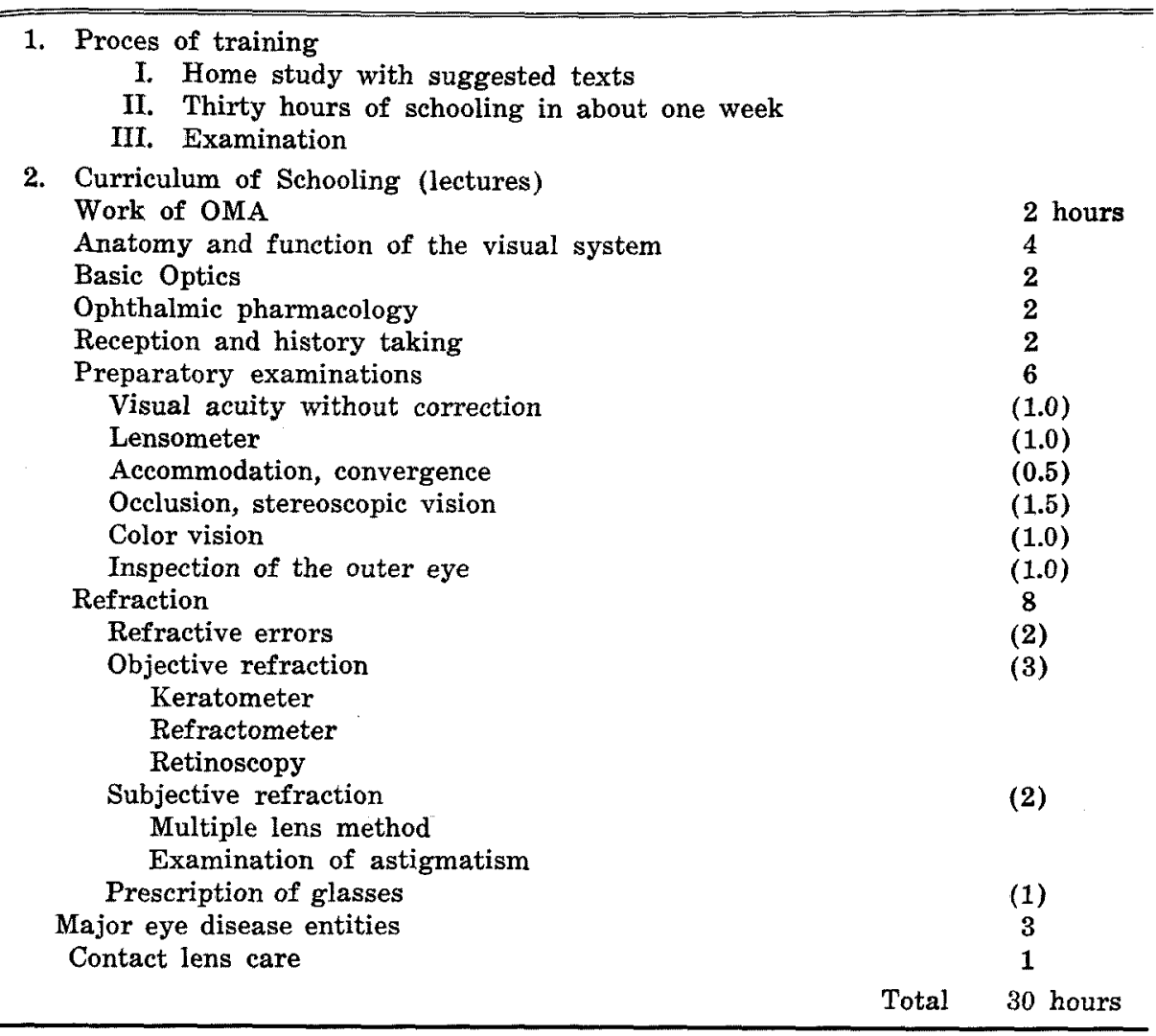

Teachers are usually ophthalmologists themselves and this is probably the most widely practiced form of ophthalmic assistance. Some nurses learn to take fluorescein angiography, fundus photography, refraction and tonometry. They can also help surgically in the operating room. Problems here are: 1) standardization of the quality of assistance, 2) ophthalmic nurses are usually unable to make use of previous experience as nurses partly due to the fact that not many private practice ophthalmologists perform surgery in Japan, 3) conflicts between the ophthalmic medical assistant and the orthoptist.

4) Optician and Optometrist

The optician and the optometrist do not necessarily assist directly in 
ophthalmic practice, however, in our classification of auxiliary personnel in eye care, this seems to be a good place to discuss them.

Under Japanese law, examination of refraction is included in medical practice and only medical doctors are allowed to practice medicine. Because of this law, the concept of professional position of optometrist has not developed in Japan. In reality, however, some 5,000 ophthalmologists are unable to perform adequate refraction to over 100 million Japanese people. Accordingly the majority of refraction has been handled by opticians. Awareness of this contradiction matched with recent movements to build schools for opticians, have caused a fiery argument as to who is to do the job of refraction-ophthalmologists or opticians.

In Japan, opticians have no professional qualifications. Usually their education is given by apprenticeship. Several training schools for opticians have recently opened but no qualification is given to the graduates. There is a movement not only among opticians but among ophthalmologists to train opticians with qualifications. In consequence, however, the qualification is not given for refraction but for filling prescriptions issued by ophthalmologists. As likewise ordinary medical prescriptions are filled by licensed pharmacists, many claims that optical prescriptions should be filled by licensed opticians arose.

There are other opticians who demand qualification for refraction. Recently a four-year college was founded for the training of optometrists. If the Japanese law were strictly followed, most working hours of ophthalmologists would be spent for refracting patients. This would be quite detrimental to hospital ophthalmologists who are responsible for carrying on the contemporary practice of ophthalmology as well as research work and education. Most ophthalmologists seem to prefer ophthalmic medical assistants as refractionist to opticians or optometrists. After considering the quality and scale of modern ophthalmic practice, it seems that the approximately 5,000 ophthalmologists with the help of twice as many ophthalmic medical assistants are still not adequate in refracting more than 30 million Japanese people who require refraction.

Nevertheless, medical schools in Japan have reached 80 in number and a yearly supply of doctors will be 8,000 in the near future. Ophthalmologists are expected to reach a total of 8,000 in ten years. With this number, all refractions will be able to be handled by ophthalmologists and their assistants. It is not known yet what the ideal solution for this matter will be, but all are searching for the best.way of treating it.

2. Health care of the eye and screening of eye diseases

Prevention of disease is the goal of medicine. Early detection and early 
treatment is the fundamental rule of medicine. These certainly apply to eye care. The more the health care and welfare advance, the greater the need in the field of prevention and early detection become.

The Japanese government and local public organizations participate in health care and perform various screening tests for members of the community. One side of screening programs comes by age while the other comes by special groups such as schools and vocational units. Table 7 summarizes these screening programs. Participants in these programs include office ophthalmologists, pediatricians, general practitioners, health nurses and nursing teachers. Health nurses work for the public health department and they usually receive lectures on eye disease once or twice a year. Nursing teachers belong to schools and in addition to their basic training for nursing teachers they can study under ophthalmologists at their school.

Table 7

Various screening programs for eye care

\begin{tabular}{|c|c|c|c|}
\hline Program & Objective & Frequency & Participant \\
\hline $\begin{array}{l}\text { Periodic } \\
\text { screening } \\
\text { program } \\
\text { for infant }\end{array}$ & $\begin{array}{l}\text { early detection } \\
\text { of visually } \\
\text { handicapped } \\
\text { infant, ambly- } \\
\text { opia and } \\
\text { strabismus }\end{array}$ & $\begin{array}{l}\text { Once a year } \\
\text { Applicable } \\
\text { infant: age } 6 \\
\text { months, } 1 \\
\text { year, } 3 \text { year } \\
\text { and } 5 \text { year }\end{array}$ & $\begin{array}{l}\text { Ministry of Welfare, } \\
\text { Prefectural office } \\
\text { of hygiene, Public } \\
\text { health department, } \\
\text { Pediatrician, Prim- } \\
\text { ary care physician, } \\
\text { nurse, dry nurse }\end{array}$ \\
\hline $\begin{array}{l}\text { School } \\
\text { screening } \\
\text { program }\end{array}$ & $\begin{array}{l}\text { Visual acuity, } \\
\text { refractive } \\
\text { errorrs, color } \\
\text { blindness, } \\
\text { external disease } \\
\text { of students }\end{array}$ & $\begin{array}{l}\text { 1-2 times a } \\
\text { year }\end{array}$ & $\begin{array}{l}\text { Ministry of Educa- } \\
\text { ton, School doctors } \\
\text { (including ophthal- } \\
\text { mologist), nursing } \\
\text { teacher }\end{array}$ \\
\hline $\begin{array}{c}\text { Vocational } \\
\text { sereening } \\
\text { program }\end{array}$ & $\begin{array}{l}\text { Visual acuity, } \\
\text { External } \\
\text { disease of } \\
\text { employee }\end{array}$ & Once a year & $\begin{array}{l}\text { Ministry of Labour, } \\
\text { Company doctors, } \\
\text { Nurse } \\
\text { (ophthalmologist) }\end{array}$ \\
\hline $\begin{array}{c}\text { Human dock } \\
\text { screening } \\
\text { program }\end{array}$ & $\begin{array}{l}\text { Glaucoma } \\
\text { Cataract } \\
\text { Retinopathy } \\
\text { from diabetes } \\
\text { or hypertension }\end{array}$ & Once a year & $\begin{array}{l}\text { Company doctors, } \\
\text { Nurse, Primary } \\
\text { care } \\
\text { ophthalmologist }\end{array}$ \\
\hline
\end{tabular}


3. Rehabilitation for the visually handicapped

Rehabilitation of visually handicapped infants is increasingly in demand. The attendants in this field have been personally trained by Dr. Harada, head of the Tokyo Metropolitan Rehabilitation Center for the Physically and Mentally Handicapped. There is no official center for such specialists in eye care, but because of the high demand several plans are presently under consideration.

4. First aid for eye emergency

The successful treatment of perforating eye injuries, chemical burns and acute attack of glaucoma depend a great deal on who gives the first aid. Lectures on eye emergency are given to ambulance attendants, health nurses and nursing teachers regularly.

\section{REFERENCES}

1. Nizetic, B.: Perspective in Ophthalmology A public health point of view, Canad. J. Ophthalmol., 8: 311-316, 1973

2. Konyama, K.: Role of Paramedical Personnels in Ophthalmic Services at Ramathibodi Hospital, Acta Soc. Ophthalmol. Jap., 82: 546-554, 1978

3. Uemura, Y.: The Present and Provisional State of Auxiliary Personnel in Eye Care in Japan. Report for the meeting of the training of auxiliary personnel in eye care, WHO, 1979 